\section{Miasta bez samochodów - alternatywa dla prywatnego środka transportu w mieście}

\section{Cities without cars - alternative for private transport in the city}

\section{Streszczenie}

Świat nieustannie rozwija się, wprowadzane są coraz nowsze technologie usprawniające życie. Jedną z nich był samochód . stale rosnaca liczbe pojazdów

zdrowego, ekologicznego środowiska, wolnego od zanieczyszczeń i hałasu sprawia, że warto żonego transportu w mieście wolnym od samochodu w przestrzen mojch pojazdów osobowych? Problematyka omówiona została na podstawie trzech znaczących przykładów: Oslo, San Francisco, a takìe miasta Masdar City.

Abstract

World is constantly developing, and new technologies that improve our life are being introduced. One of them was a car which is still present in urban spaces. The driver became the dominant traffic user. Urban interiors are overwhelmed by parking spaces which are present everywhere around. Without them the city could not function, having to adopt constantly increasing number of vehicles.

is ang attention to a hach, clean environment, free from pollution and noise, makes it worth considering whether there is an alternative to the car in urban space? What changes brings the idea of sustainable transport in a city free of private (asto Masdar City.

Słowa kluczowe: Miasto, użytkownik, samochód, zrownowazony
Keywords: City, user, car, sustainable transport, innovations

\section{WPROWADZENIE}

$W$ dzisiejszym zagonionym, szybko rozwijającym sie zmiennym świecie zdawać by się mogło, że transport kolowy, a w szczególnosci samochody towarzyszą nam d zawsze. Obecne pokolenia nie wyobrazaja sobie życia bez prywa in Wrowadzenie transporta kolowego do miasta spo

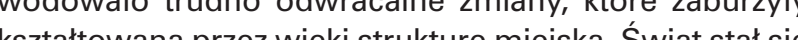

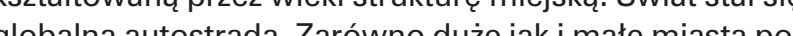
globalną autostradą. Zarowno duże jak i male miasta poprzecinane są siatkami szerokich ulic często stanowiąc

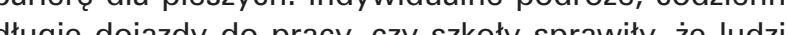
digie dojazdy do pracy, czy szkoly sprawily, że ludzie kolúa się od sicie, spędzaja więcej czasu w samot-

\section{INTRODUCTION}

today's fast-moving, fast-developing and contantly changing world, it could seem that wheeled transport, especially cars, has always accompanied us in our life. Current generations cannot imagine life without private, easily accessible transport. Althoug the cars have already dominated the city space, their number is constantly growing.

Addition of wheeled transport to the city resulted in difficult reversible changes that disturbed urba world became global highway. Both large and smal cities are cut by grid of wide streets, often becoming barrier to pedestrians. Individual journeys, everyday long drives to work or school isolated people from each other. They spend more time alone. Possibilities that car ownership gave caused uncontrolled growth tructure which has been shaped for centuries. The sprawily także niekontrolowane rozrastanie się mias to nowsze technologie umożliwiające szybszą jazdę stają się często przyczyną licznych wypadkow, stanowia niebezpieczeństwo dla pieszych, rowerzystów będacych prawowitymi użytkownikami w ruchu ulicznym. To właśnie samochody są $\mathrm{w}$ dużym stopniu źródłem zanieczyszczenia powietrza, zwiększenia efektu globalnego ocieplenia.

Odejście od idei ruchu pieszego powoduje zanikanie stref przeznaczonych dla życia publicznego, a także zieleni w miastach. Granic administracyjnych nie da sie rozciągać w nieskończoność, a mimo to stale rosnąca liczba samochodów sprawia, że powstaja nowe, rozległe parkingi zabierające przestrzeń wspólną. Wszystko to spowodowane było krótkowzrocznością i próbą zaspokojenia potrzeb mieszkańców. Widok samochodów na ulicach przytłacza i dominuje nad strukturą miejską. Warto zastanowić się czy w idei miasta o zrównoważonym transporcie istnieja alternatywy komunikacyjne dla prywatnego środka lokomocji. Czy samochód jest jedyną wygodną i szybką formą przemieszczania się? Czy zniesienie jego dominacji w mieście wpłynie na zwiększenie mobilności, poprawę dostępności, ułatwienie i poprawienie jakości życia publicznego i jednostki?

\section{MIASTA BEZ SAMOCHODÓW}

Już dziśs pierwsze projekty zmian pojawiają się na całym swiecie. Madryt planuje stworzenie ulic, w których dom nującymi użytkownikami ruchu będą piesi. Wielopasmowe arterie zastępowane są przez parki. Miasto Chengdu w Chinach zostało zaprojektowane tak, by czas przejścia do wszystkich najważniejszych miejsc wynosił mniej niż 15 minut. Władze Hamburga jaki innych miast niemieckich holenderskich, czy duńskich chcą ułatwić transport pieszy i rowerowy zarówno mieszkańcom jak i przyjezdnym tak by nie musieli sięgać po samochody. Wprowadzanie wielu zakazów dla dwuśladowców sprawia, że podróże rowerem, czy komunikacją miejska, są po prostu łatwiejsze i szybsze, a co za tym idzie częściej i chętniej wybierane. ${ }^{3}$ Niezwykła rolę w rozwoju miast odegrało zjawisko Nowego Urbanizmu, którego głównym założeniem jest przywrócenie dawnej formy i struktury miejskiej dziek ekologicznym, przyjaznym rozwiązaniom i uporzadkowaniu infrastruktury komunikacji zbiorowej, pieszych rowerzystów, krajobrazu.

Idea, miasta przyszłości, bez samochodu tworzy się na naszych oczach. Elektryczne, a także bezzałogowe, autonomiczne pojazdy, systemy współdzielenia środków transportu, latające taksówki to tylko niektóre z nowości technologicznych dostępnych niemal na wyciągnięcie ręeki.

Wybijającymi się przykładami miast wprowadzające zmiany w transporcie są przede wszystkich propozycje z Oslo, San Francisco, a także w nowoprojektowanym Masdar City.

OSLO, NORWEGIA

Oslo - „kosmopolityczny ośrodek peten obiektów ar of cities to rural areas, deformation of their compact enable faster driving often cause of numerous accidents, becoming a danger for pedestrians, cyclists even though they are legitimate users in street traffic. Cars are in a large scale a source of air pollution, increasing the effect of global warming.

Glance off the idea of pedestrian movement causes disappearance of public spaces, as well as greenery in the cities. Administrative boarders cannot be extended ceaselessly, and yet still growing number of cars is the reason for forming new, large parking lor ing

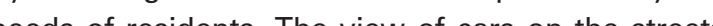

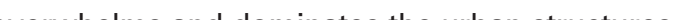
is worth considering whe the there are ater. for private venicles in idea of cily with surtaine for priverts is the car idea of cily with sustainable form of movene car will the anditis of nance in the cly inp will the aboltion of its domiity of public life and life of individuals?

\section{CITIES WITHOUT CARS}

Nowadays first projects are already appearing all over the world. Madrid plans to create streets where pedestrians will be dominant traffic users. Multiband roads are replaced for parks. City of Chengdu in Chin has been designed so that the time of transition to al most important places was reduced to less than fifteen minutes. Government of Hamburg, as well as other German, Dutch and Danish cities want to facilitate pedestrian and cyclist movement for both residents and visitors so that they do not need to use cars. Addition of many prohibitions for vehicles makes travelling by bike or public transport easier and faster, and thus more often and willingly chosen.

Incredible role in the development of cities has been layed by the phenomenon of New Urbanism, whose ming friendly solutions and arrangement

of public transport, pedestrians, cyclist infrastructure and landscape.

Te idea of the city of the future, without car is being created before our eyes. Electric and autonomous vehicles, system of sharing transport, flying taxis are only some of technological news available almost a our fingertips.

Emerging examples of cities which are being im proved by changes in transport are, first of all, projects from Oslo, San Francisco, as well as newly designed Masdar City.

\section{OSLO, NORWAY}

Oslo - "cosmopolitan center full of architectural objects, museums, restaurants and shops at world 


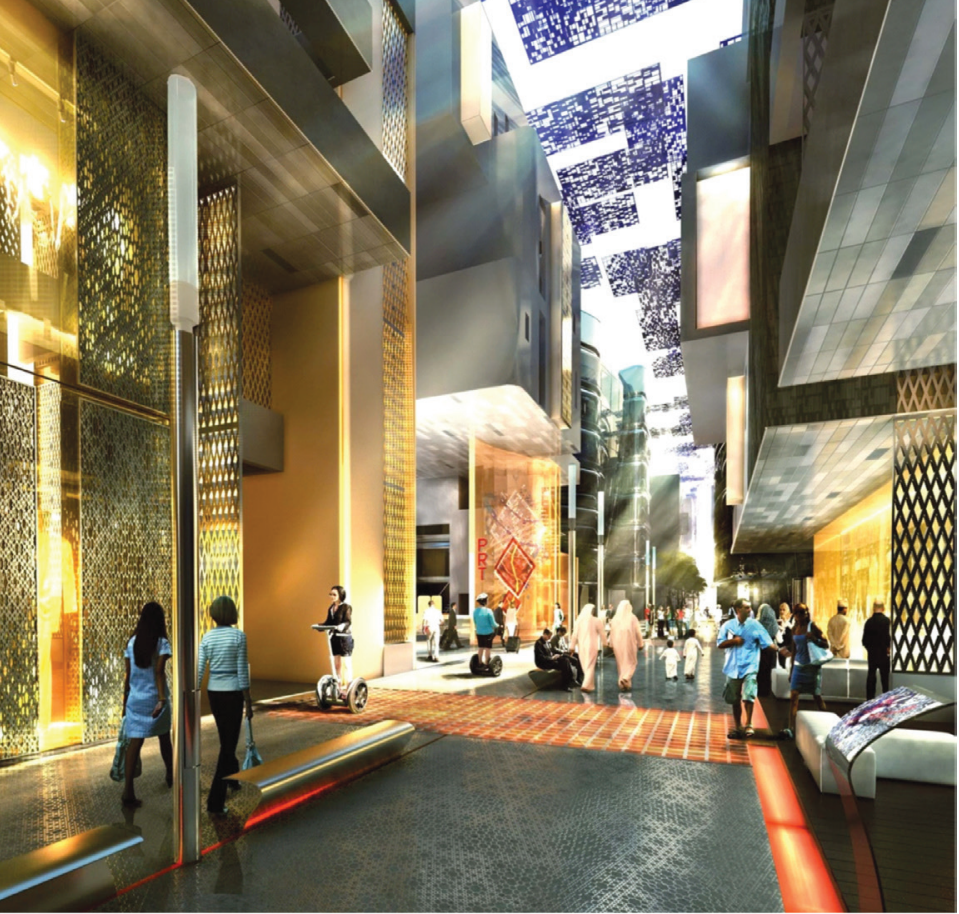

środki transportu łącząc się tworzą zintegrowaną jednostkę miejską zaprojektowaną dla czterdziestu tysięcy mieszkańców i pięcdziesięciu tysięcy pracownikow.

Płynne przejścia pomiędzy funkcjami mieszkalnymi, publicznymi, kulturowymi i edukacyjnymi mają dawa podstawy dla przyjaznej dla ruchu pieszego tkanki miejskiej, w której społeczeństwo będzie mogło bezpiecznie i zdrowo żyć." Piesi i rowerzyści mogą swobodnie przemieszczać się i wspótistnieć w pełnej symbiozie. Transport pełni przewodnią rolę $\mathrm{w}$ ksztattowaniu nowoczesnego spoleczenistwa i miasta. Zurbanizowan przestrzen jest przyjazna dla mieszkanców. Struktura projektowana wokoł ludzi. Nie odczuwają oni potrzeby posiadania własnego, prywatnego środka transportu. Kompaktowa i zarazem kompleksowa forma urbanistyczna pozwala na efektywne wykorzystanie nowych form komunikaji publicznej. Są nimi przede wszystkim Personal Rapid Transit (PRT) czyli kilkuosobowe elektryczne, autonomiczne pojazdy bezzałogowe umożlwiające latwe i szybkie przemieszczanie się do punktu docelowego. Bezkolizyjne kapsuły poruszają się po wy znaczonych trasach nieingerujących w tkankę miejska obecne $w$ formie podziemnej i nadziemnej. Według prowadzonych nieustannie badan ta forma transportu zapewnia ponad $99 \%$ efektywności i pozwala na znaczne zmniejszenie sladu ekologicznego. ${ }^{12}$ Stanowi znaczące osiągnięcie nie tylko dla Masdar City, ale także całego świata. Funkcjonalność idzie w parze z jakościa.

PRT to nie jedyna forma dostępnych środków transportu. Obecne są również General Rapid Transport (GRT) Light Rail Transit (LRT) oraz Metro's. Dzięki łatwiej dostępności pozwalają one społeczeństwu dotrzeć kom fortowo i szybko w każde miejsce, nawet na odległych krańcach miasta. Miejscowi nie będą odczuwali potrzeby sięgania po własny srodek transportu. Obecność alternatywnych form komunikacji daje możliwość zminimalizowania powierzchni zajętych przez miejskie arterie i nie stanowi barier dla tętniących życiem współdzielonych przestrzeni publicznych. Pozwala to tatwiej stwo

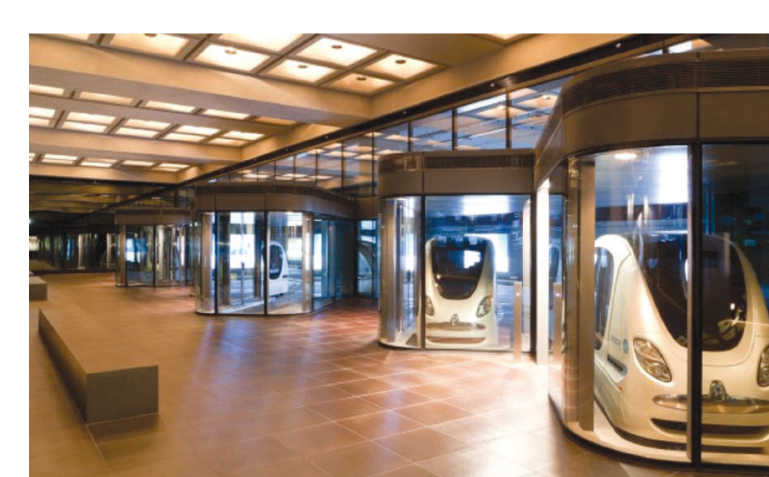

II. 11. Przestrzenie publicznie $w$ Masdar City przyjazne dla pie-
szych. [Zródto: www.fosterandpartners.com/projects/masdar-city// / Public spaces in Masdar City are friendly for pedestrians
[source: www.fosterandpartners.com/projects/masdar-city/

II. 12. Personal Rapid Transit (PRT) w Masdar City. [Ĺródto: masdar
ae] / Personal Rapid Transit (PRT) in Masdar City. [source: masdaraea]

public spaces, cultural and educational buildings provides basis for pedestrian-friendly urban structure i which society can live safely and healthily." Pedestrians and bikers can freely move and coexist in ful symbiosis.

Transport leads main role in shaping modern society and city. Urban spaces are friendly for residents. Structure is designed around people. They do not feel the need to own their private car.

Compact and comprehensive urban form allows for effective use of new ideas of public transport. These are primarily Personal Rapid Transit (PRT), which is sharing electric, autonomous no-driver vehicle tha allow easy and fast travelling from point to point. Non-collision capsules move on designate to point. above-ground roads which do not interfere with urban sprocs. According to constive gong with urthis form of trench this

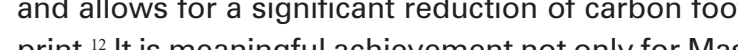
print. dar Cly, but also for the whole world. Functionality goes together with quality.

PRT is not the only accessible form of transport. General Rapid Transport (GRT), Light Rail Transit (LRT) and Metro are also present. ${ }^{13}$ With easy access they allow people to reach their destination comfortably and fast even at the far end of the city. Local inhabitants would not feel need to reach their own car. The presence of alternative transport gives chance to minimize areas occupied by wide roads and does no create barriers to public spaces. This makes easier to create relationships between people and urban structures in which they can feel safe.

Although construction of the city which was planned to the end of 2016 is still going, the dream of intelligent, self-sufficient, car-free Masdar City slowly becoming a reality. Even though people are not ye used to such big technological leaps, the project is rzyc relacje człowieka i tkanki miejskiej, w której może czuc się bezpiecznie.

Choć budowa miasta, której zakonczenie planowano na 2016 rok wciąż trwa, marzenie o inteligentnym, samowystarczalnym, wolnym od samochodow Masdar City powoli staje się rzeczywistoscią. Choc ludzie nie są jeszcze przyzwyczajeni do tak dużego skoku technologicznego, wyraźnie widoczne są inspiracje projektem na całym swiecie. ${ }^{14}$ Masdar ksztaltuje nowe standardy miasta.

\section{PODSUMOWANIE}

Wspołczesnie silnie widoczny jest powrót do pierwotnych form i struktur miejskich. W obrębie miast coraz częściej rezygnujemy z przemieszczania się samochodami na rzecz publicznej komunikacji miejskiej, czy spaceru. Coraz więcej pojawia się także osób podróżujących na rowerach. Transport odpowiada na potrzeby miesz kańców. Pozwala im na stworzenie relacji z miejscem nie maszyną.

Nowoczesne technologie, innowacje i zasada projektowania zrownowazonego transportu pozwala na zmnie szenie śladu ekologicznego, przywrócenie życia w miescie, stworzenie bezpiecznego i zdrowego środowiska do pracy, rozwoju.

Przedstawione w artykule przykłady z Oslo, San Francisco i Masdar City wyraźnie wskazuja, że samochód nie jest jedyną szybką i wygodną forma przemieszczania się. Zniesienie dominacji prywatnego środka transportu w mieście polepsza kondycję infrastruktury i przestrzen publicznych. Ustępuje nowym systemom współdzielenia, wypożyczania pojazdów, które zmniejszają ich liczbę. Daje możliwość rozwoju komunikacji publicznej i powstawania jej nowych form. Elektryczne autonomiczne samochody $i$ inteligentne systemy łączenia ich $w$ jedn sieć pozwalaja ograniczyć ilość wypadków na drogach. Pojazdy znikają w podziemnych liniach komunikacyjnych. Miasta promuja ruch pieszy i rowerowy dostosowując infrastrukturę do potrzeb mieszkańców.

Choć obecnie często miejsca bez samochodów są jeszcze niezagospodarowane i zdają się być puste, jednak widoczne są ruchy w kierunku pozytywnych zmian. Ludzie zaczynają przyzwyczajać do nowej, lepszej rzeczywistości. Chcą zaangażować się w kreowanie lepszego zdrowszego i bezpieczniejszego jutra.

PRZYPISY

stawie danu na šwiecie zanotowano 1,1 miliarda samochodów. Na podda, a do 2040 roku wrosonie niemal dwukrotnie. Ile jest sammochodów $n$

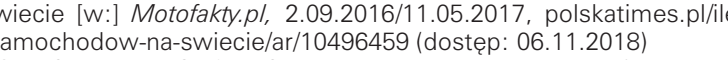
nal Books, 2000/2002. insider, New York 2.02.2017, www.businessinsider.com/cities-going-car - ree-2017-2? R= T\#people-in-chengdu-will bid able-to-walk-anywher Stolica o wielkomiejskim charakterze [w]

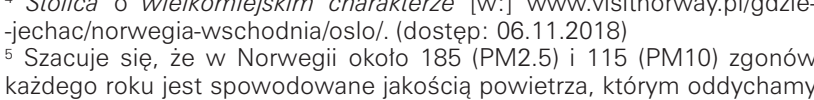
kazdego roku jest spowodowane jakoscia powietrza, którym oddychamy
na co dzieñ oraz zawartymi w nim pytów zawieszonych. Air pollution

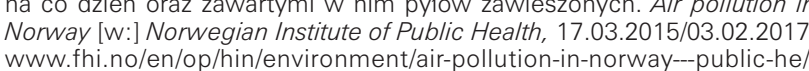
Www.thi.no/en/op/hi/
(dostẹp: 06.11.2018) surely becoming inspiration around the world. ${ }^{14}$ Masdar shapes new standards of the city.

\section{SUMMARY}

Nowadays, the return to original forms and urban structures is strongly visible. Within the cities it is more and more common to resign from cars for public transport or walk. More people are also biking. Transport responds to the needs of residents. . The vehicle.

New technologies, innovations and idea of sustainable transport design allows to reduce carbon footprint, re-establish life in the city, create safe and Delthy environment to work and self-development. Examples of Oslo, San Francisco and Masdar City presented in this article, clearly indicate that the car is not the only fast and convenient form of travelling. The abolition of the dominance of private vehicle in the city improves condition of infrastructure and public spaces. It gives the way to new sharing and rental systems that reduce their number. It gives the opportunity to develop public transport and in vent its new forms. Electric, autonomous cars and intelligent systems of communication between them educe amount of accidents on the roads. Vehicles disappearing in underground transit tunnels. Cities promote walking and cycling traffic and adapt infrastructure to the needs of residents.

Although nowadays it is common that places without cars are undeveloped and seem to be empty, but projects towards positive changes are visible. People are getting used to new, better reality. They want to be involved in better, healthier and safer tomorrow.

ENDNOTES

- In 2015, 1.1 billion cars were recorded in the world. Based on
estimates, in 2025 this number will reach 1.5 billion, and by 2040 it

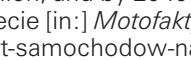
-swiecie/ar/10496459 (access: 06.11.2018)

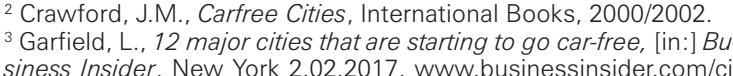

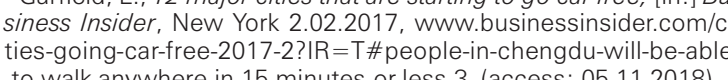

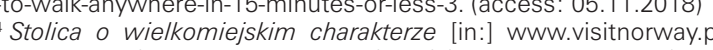
gdzie-jechac/norwegia-wschodnia/oslo/. (access: 06.11.2018)
5 It is estimated that in Norway about 185 (PM2.5) and 1115 (PM10) deaths each year are caused by air quality and particulate mat
ter we breath every day. Air pollution in Norway [in:] Norwegian tic Health, 17.03.2015/03.02.2017, www.fhi.no/en 06.11 .2018 I
${ }^{6}$ Rocque, M., Cities without cars [in: I SmartCities World, 23.08.2017, without-cars. (access: 06.11.2018)

ur-oslo/green-oslo/. (ac8. San Francisso: Meeting the Smart City Chall/enge [in:] www.sm-
ta.com/sites/default/files/projects/2016/SF\%20Smart\%20City\% 20 ta.com/sites/default/files/(projects/2016/SF\%20 20 Smart\%20City\%20 9 Masdar City - zielone miasto przysztósci na pustyni lin:] Ogro-
dolandia.pl, 11.10 .2016 , ogrodolandia.pl/masdar-city. (access 05.11.2018) 11.10.2016, ogrodolandia.pl/masdar-Chy. laccess: 10 Alameri, M.. The car free city model [in:] Urban Transport XVII,
WIT Press, 2011, p. 143 . 
${ }^{6}$ Rocque, M., Cities without cars [w:] SmartCitiesWorld, 23.08.2017, www.smartcitiesworld.net/special-reports/special-reports/cities-without-cars. (dostęp: 06.11.2018)

7 Green Os/o [w:] Www.visitoslo.com/en/your-oslo/green-oslo/. (dostęp: 6.11.2018)

${ }^{8}$ San Francisco: Meeting the Smart City Challenge [w:] www.sfmta.com/sites/ default/files/projects/2016/SF\%20Smart\%20City\%20Challenge_Final.pdf, s.1. (dostęp: 08.11.2018)

9 Masdar City - zielone miasto przyszłości na pustyni [w:] Ogrodolandia.pl 11.10.2016, ogrodolandia.pl/masdar-city. (dostęp: 05.11.2018)

${ }_{10}$ Alameri, M., The car free city model [w:] Urban Transport XVII, WIT Press, 2011, s.143.

${ }^{11}$ Investment and learning opportunities at Masdar City [w:] masdar.ae/en/masdar-city/detail/masdar-city-abu-dhabis-modern-sustainable-city. (dostęp: 05.11.2018) 12 PRT@99.7\% since 2010 [w:] 2getthere 30.11.2016, www.2getthere.eu/category/masdar/ (dostep: 06.11.2018)

${ }^{13}$ General Rapid Transport (GRT) to sieć komunikacji publicznej zapewniająca łatwą dostępność, mobilność w obrębie całego miasta. Light Rail Transit (LRT) czyli szybki tramwaj działający na zasadzie podobnej do kolei miejskiej, ułatwiając przemieszczanie się do i z Masdar City łącząc jego centrum z innymi okolicznymi jednostkami miejskimi. Alameri M., The car free city model [w:] Urban Transport XVII, WIT Press, 2011, s. 147.

${ }^{14}$ Na początku 2018 roku zanotowano jedynie 1300 mieszkańców i niecałe 3500 pracowników w Masdar City. Obecnie miasto nazywane jest zielonym miastem-duchem. Obecna data ukończenia budowy to 2030 rok. www.scmp.com/week-asia/business/article/2133409/oil-rich-abu-dhabis-masdar-city-green-oasis-or-green-ghost-town. (dostęp: 6.11.2018)

\section{BIBLIOGRAFIA}

[1] Alameri M., The car free city model [w:] Urban Transport XVII, WIT Press, 2011, s. 143-154.

[2] Crawford, J.M., Carfree Cities, International Books, 2000/2002.

[3] Fojud, A., Czy istnieje alternatywa dla samochodu w mieście?, [w:] designforall.pl, Poznań 17.09.2014, www.designforall.pl/czy-istnieje-alternatywa-dla-samochodu-w-miescie/. (dostęp: 05.11.2018)

[4] Garfield, L., 12 major cities that are starting to go car-free, [w:] Business Insider, New York 2.02.2017, www.businessinsider.com/cities-going-car-free2017-2?IR=T\#people-in-chengdu-will-be-able-to-walk-anywhere-in-15-minutesor-less-3. (dostęp: 05.11.2018)

[5] Jagiełło-Kowalczyk, M., Zrównoważone osiedla bez samochodów...i bez mieszkańców. [w:] Srodowisko Mieszkaniowe, nr 13, Kraków 2014, str. 81-88.

[6] Rocque, M., Cities without cars [w:] SmartCitiesWorld, 23.08.2017, www. smartcitiesworld.net/special-reports/special-reports/cities-without-cars (dostepp: 06.11.2018)

[7] Green Os/o [w:] www.visitoslo.com/en/your-oslo/green-oslo/. (dostęp: 6.11.2018 [8] Investment and learning opportunities at Masdar City [w:] masdar.ae/en/ masdar-city/detail/masdar-city-abu-dhabis-modern-sustainable-city. (dostęp: 05.11.2018)

[9] Masdar City - zielone miasto przyszłości na pustyni [w:] Ogrodolandia.pl, 11.10.2016, ogrodolandia.pl/masdar-city. (dostęp: 05.11.2018)

[10] San Francisco: Meeting the Smart City Challenge [w:] www.sfmta.com/ sites/default/files/projects/2016/SF\%20Smart\%20City\%20Challenge_Final.pdf. (dostęp: 08.11.2018)

[11] Stolica o wielkomiejskim charakterze [w:] www.visitnorway.pl/gdzie-jechac/ norwegia-wschodnia/os/o/. (dostęp: 06.11.2018)
11 Investment and learning opportunities at Masdar City [in:] masdar.ae/en/masdar-city/detail/masdar-city-abu-dhabis-modern-sustainable-city. (access: 05.11.2018)

12 PRT@99.7\% since 2010 [in:] 2getthere 30.11.2016, Www.2getthere.eu/category/masdar/ (access: 06.11.2018)

13 General Rapid Transport (GRT) is a public transport network providing easy accessibility, mobility throughout the city. Light Rail Transit(LRT) is fast tram working on a principle similar to the fast suburban train, making it easier to move from and to Masdar City connecting its center with nearby cities. Alameri M., The car free city model [in:] Urban Transport XVII, WIT Press, 2011, p. 147.

${ }^{14}$ At the beginning of 2018, only 1,300 inhabitants and less than 3,500 employees were recorded in Masdar City. Currently city is called the green ghost town. Construction completion date is planned on 2030. www.scmp.com/ week-asia/business/article/2133409/oil-rich-abu-dhabis-masdar-city-green-oasis-or-green-ghost-town. (access: 6.11.2018)

\section{BIBLIOGRAPHY}

[1] Alameri M., The car free city model [in:] Urban Transport XVII, WIT Press, 2011, p. 143-154.

[2] Crawford, J.M., Carfree Cities, International Books, $2000 / 2002$

[3] Fojud, A., Czy istnieje alternatywa dla samochodu w mieście?, [in:] designforall.p/, Poznań 17.09.2014, www.designforall.pl/czy-istnieje-alternatywa-dla-samochodu-w-miescie/. (access: 05.11.2018)

[4] Garfield, L., 12 major cities that are starting to go car-free, [in:] Business Insider, New York 2.02.2017, www.businessinsider.com/cities-going-car-free-2017-2? IR=T\#people-in-chengdu-will-be-able-to-walk-anywhere-in-15-minutes-or-less-3. (access: 05.11.2018)

[5] Jagiełło-Kowalczyk, M., Zrównoważone osiedla bez samochodów...i bez mieszkańców., [in:] Środowisko Mieszkaniowe, nr 13, Kraków 2014, p. 81-88.

[6] Rocque, M., Cities without cars [in:] SmartCitiesWorld, 23.08.2017, www.smartcitiesworld.net/special-reports/special-reports/cities-without-cars. (access: 06.11.2018)

[7] Green Os/o [in:] www.visitoslo.com/en/your-oslo/green-oslo/. (access: 6.11.2018)

[8] Investment and learning opportunities at Masdar City [in:] masdar.ae/en/masdar-city/detail/masdar-city-abu-dhabis-modern-sustainable-city. (access: 05.11.2018)

[9] Masdar City - zielone miasto przyszłości na pustyni [in:] Ogrodolandia.pl, 11.10.2016, ogrodolandia.pl/masdar-city. (access: 05.11.2018)

[10] San Francisco: Meeting the Smart City Challenge [in:] www.sfmta.com/sites/default/files/projects/2016/ SF\%20Smart\%20City\%20Challenge_Final.pdf. (access: 08.11.2018)

[11] Stolica o wielkomiejskim charakterze [in:] www.visitnorway.pl/gdzie-jechac/norwegia-wschodnia/os/o/. (access: $06.11 .2018)$ 